\title{
Tnyafar: Women, Livelihoods Strategy in Selaru Island, West Southeast Maluku District
}

\author{
Junianita Fridianova Sopamena*, August Ernst Pattiselanno \\ Department of Agribusiness, Faculty of Agriculture, Pattimura University, Ambon, Indonesia \\ *corresponding author : junianitasopamena@gmail.com
}

Junianita Fridianova Sopamena is Lecturer from Agribusiness Department, Faculty of Agriculture, Pattimura University Ambon Indonesia. Her research interrests are in role of women, gender studies, and human ecology. Her contact email : junianitasopamena@gmail.com as Correspondence email.

August Ernst Pattiselanno is a Profess or Rural Sociology at Faculty of Agriculture, Pattimura University Ambon, Indonesia. His research interrests are in rural sociology, social change, and livelihood strategies,. His contact email : pattiselannoaugust@gmail.com.

\begin{abstract}
Tnyafar as local wisdom is closely related to women as a regulator offamily income strategy. Through tnyafar women express alternatives to meet the needs of families in a variety of conditions, both social, economic, and physical environment. One of the strategies undertaken in tnyafar concept is to do farming activities with a variety of food crops, plantation crops, even developed a special food crops currently facing food emergencies also utilization of coastal areas for seaweed commodities. Thus, women have demonstrated the role of implementing farming activities had even surpassed conception of agroforestry is known so far. Therefore, at this time the role of women not only dominant in the domestic area, but be extended to cover public areas.
\end{abstract}

Keywords- local knowledge, women, livelihood strategies, small island, dusun, and arin.

\section{INTRODUCTION \\ Background}

Women role was recognizable since a long ago. Communal tradition divided work categories into light and heavy. Such work division has been attended by Tanimbar community in Maluku Tenggara Barat. Men were charged with heavy work, including opening field for a new planting land, cutting trees, clearing spot for business location, and others. Women only continued what men did after heavy work finished. It means that after field was opened, then activities of preparing seeds, planting, managing against pest and disease, weeding, harvesting and marketing, were works that must be done by women, and it became their legacy throughout generations. All these processes were given a label of "Tnyafar" where households left their village and settled temporarily on their farmland. Indeed, Tnyafar process was a local wisdom that placed women in an important position for fulfilling household necessities. Early description of Tnyafar was explained as following:

1. Women role was aligning with Tnyafar implementation, where women role was extensive and severe. It impacted on the continuity of Tnyafar which also influenced the sustainability of fulfilling household necessities because Tnyafar was also considered as a strategy of household livelihood.

2. Women activities were compatible to Tnyafar implementation because the displacement of women role dominated public sector, meaning that women was previously occupying domestic sector, but their role shifted from domestic to public realm, with a possible domination in public sector in the future.

The community of Selaru Island was the occupant of coastal part of the island. Their local economic was dominated by farming and fishery sectors. In farming sector, the community cultivated crops including tubers, legumes, corns, vegetables, and dry-land rices. Farming and fishery sectors were managed on Tnyafar. Land-open method for shifted-farming or gardening was using slash-and-burn system. It involved traditional technology and local technique, and it was still influenced by customs that regulated the relationship between human and soil/land. In some villages, the opening of new garden must apply procedures in the customs although few changes had recently been made (Atsea, 2011). Pattiselanno et al (2015) explained that in recent days, fallow period was shorter because people tended to look for the land nearby their residence to be cultivated as garden. It was evident possibly because primary forest was too far from the village. The opening of new road could help shortening the journey the farmers must take to go to their gardens because it provided clean path free from bushes that could be past over by farmers by riding on rented-motorcyclist. 
As shown by Cabuy et al (2012) in Papua and Ratnawati et al (2014) in Jogjakarta, local wisdom was important element in community life. Local plants were cultivated on immediate environment in order to produce farming work. Tnyafar attempted to create the relationship between all elements in the livelihood system of the households. Tnyafar helped satisfying the living standard of the households in sustainable ways. Tnyafar gave a consequence of fixed-work which at least prevented the possibility of shifted-farming and also reduced the unfavorable impact of environmental degradation. All of them allowed the households to have livelihood sustainability. This reality was the manifestation of local wisdom. From this matter, problem of research could be made: Why Tnyafar as main economic process of the households could be said as local wisdom in the environmental sustainability context and also be useful in creating livelihood satisfation sustainability?

\section{Objective}

The objective of research was to analyze the existence of Tnyafar as local wisdom of the community.

\section{METHOD OF RESEARCH Qualitative Approach}

This research used qualitative approach. Main strategy to operate this approach was case study as suggested by Yin (1996), Stake (1995), Bogdan, R.C and Biklen, S.K., (1982), and Creswell (1994). Case study was used because it was relevant with the articulation of Tnyafar which until today it was still continually professed by Selaru Island community. Case study also allowed the author and respondents to develop interaction and dialog, as explained by Yin (1996) and Stake (1995).

Location of Research, Population and Informants of Research

Selaru Island belonged to the admnistration area of Selaru Island District, West Southeast Maluku Regency (MTB Regency). Selaru Island was one of few islands in MTB Regency occupied by Tanimbar Ethnic as the native inhabitant. The administrative area in Selaru Island District comprised of five villages. The distinctive marker of the inhabitant was high capacity of migration among Tanimbar Ethnic in Selaru Island. This ethnic could settle on few islands with few inhabitants, and also assimilate easily with community in few villages in the Selaru Island or beyond the island.

Research population was Selaru Island community who conducted Tnyafar. Informants included men and women who occupied Tnyafar. There were 25 informants, and their status were leader, former-leader and member of Tnyafar. The leadership structure of
Tnyafar consisted of Chair, Secretary, and Treasurer. Mostly, treasurer was a woman, but in some Tnyafar, woman worked as secretary. Other Tnyafar even selected woman as the Chair. The Head of Customs was key informant who understood well the working structure and the activity of Tnyafar.

\section{Case Selection, Deep Interview, and Participative Observation}

For obtaining the information, the author asked some questions to the key informant, precisely the Head of Customs as the community figure in Adaut Village in Selaru Island, who regularly conducted Tnyafar local wisdom. Snowball technique as explained by Moleong (1989) was used to obtain other informants. Deep interview was performed to obtain more relevant informations. Focused Group Discussion was implemented to strengthen information previously obtained. Participative Observation (Moleong, 1989:138) was also conducted because it allowed the author to see, to feel and to sense the world, events, and social symptoms in the way the actor did. It was also helpful to establish mutual understanding between the author and the actor (inter-subjectivity).

\section{Data Analysis}

Miles and Huberman (1992:15-21) mentioned about three paths in analyzing qualitative data. It started with continuous data reduction that involved some activities such as selecting, concentrating attention, making simplification and abstraction, and transforming data given by informants. It was followed by data presentation which displayed important information about Tnyafar. The presentation helped the author in preparing conclusion and next action. Conclusion remark included a verification on previous conclusion about Tnyafar as local wisdom.

\section{RESULTS AND DISCUSSION}

\section{The Development of Women Role}

The problem was related with the displacement in how to preserve the culture and how to utilize natural resource. It caused a role gap between men and women. Women existence also displaced threatening the traditional role of rural women. The impact of social change and also of intensive exploitation of natural resource forced women to have narrower engagement. When the nature was explored to be human settlement, forest must be the subject of utilization. Women were forced to support the fulfillment of household necessities, meaning that they must seek for additional income, including being the laborer in various activities. Such double roles keep the gap between two genders becoming wider. As a result, it marginalized the function of women in the household. 
According to Andriani and Euis Sunarti (2008), traditional role of women concerned with taking care of domestic affair, while men did subsistence work. But, it is not a rare to find women in livelihood employment. Therefore, women indeed incur double charges. In household affair, women must manage household resource to produce welfare. On agriculture, double livelihood pattern was a strategy for survival because relying only on farming output was not adequate to fulfill household necessities. All members of household must enter employment market outside farmland. Dharmawan (2007) said that livelihood strategy was a tactic and an action developed by individual or group to maintain their existence, social infrastructure, social structure, and cultural value system. Livelihood strategy used by each man and woman may differ to each other (principally, it was gender-oriented).

Scoones (1998) admitted that in applying livelihood strategy, farmer household utilizes various resources to maintain their life. Livelihood strategy was classified into three categories such as: farming livelihood engineering, which utilizing the farming sector in efficient and effective ways by considering various external inputs such as technology and workers (intensification), or by enhancing the cultivated land (extensification); double livelihood pattern (diversification), which looking for jobs out of farming land to increase household income or to deploy household-based workers (father, mother and kids) for additional income; and finally, spatial engineering (migration), which represents a mobility to other region out of the village, either permanently or circularly to obtain additional income.

Puspitawati (2012) insisted that gender was reflecting the difference on role, function, status and responsibility between men and women, as a consequence of socio-cultural construction internalized through a socialization process from a generation to another generation. Instruction of Indonesia Republic President No.9/2000 about Gender Equality had stated that men and women must be given equal standing to ensure their usage of opportunity and rights as human with equal role and participation into political, economical, socio-cultural, national defense and security sectors, and also into the enjoyment of the development result. Gender Equality was important in the household because it kept men and women to have equal standing.

\section{Tnyafar : The Implementation of Functions of Production and Consumption, Settlement and Value Inheritance}

The existence of Tnyafar in Selaru Island was proved a fact that the community of the islad professed local wisdom. It involved some activities. Livelihood satisfaction method was adaptable to the surrounding nature. The crops were planted by adjusting them with immediate weather and planting culture the immediate community had used. General farming, including fishery, was performed on Tnyafar. The community might exploit land and sea sides in accordance to weather. In dry season, the harvest of the crops might be not good. Therefore, the activity was oriented toward the sea, and it involved cultivating sea grass, collecting sea cucumber and lola, and catching fish with rod. During rain season, farming was dominant. The longevity plant, such as coconut, was main crop to consider because it also produced copra. Review of Jiri, Mafongoya, Mubaya, and Mafongoya (2016) gave evidence that scientific estimation on the condition had failed to help smallholding farmers because of their incapacity to access this information. Sometimes, there was a dispute between scientific method and customs-based prediction. The prediction of customs was without challenge, and therefore, it was directly used by community as the reference in selecting adaptive strategy although it was difficult by farmers to integrate customs with scientific knowledge. A similar reality was reported by Chanamuto and Hall (2015). Farmer-women were quite susceptible to climate change that affected greatly their farming activity, and therefore, breeding the livestock was becoming the other option. Indeed, every household did radical action when their food security was threatened. This reality was understood by farmers in Tnyafar, and even considered as reasonable habit that preceded the maturity of local wisdom in Tnyafar. Besides relying on the commodities such as tubers and corns, the community also planted certain commodity that would only be stored and even never be consumed when main food was secured. This commodity (including sago with harsh fiber and red color - mawere) was cultivated in Tnyafar because it could gave food reserve during food crisis.

Local wisdom was applied in Tnyafar to regulate the harvesting of crops and sea products. At certain times, coconut was subjected to Sasi (the prohibition of harvest on certain rules) in order to maintain the productivity of the plant. However in the case of immediate need, such as school tuition, the owner of coconut might ask for allowance (Exceptional Sasi) for meeting such need. The procedure of this Exceptional Sasi was varying across each plant owner. It did not comply anymore with the customs but it was submissive to the Church Organization. Such procedure was strongly effective because the deviation of this sasi would be considered as violating God's Rule. The penalty was more heavier than monetary fine.

Sea products were also subjected to Sasi, especially for sea cucumber and lola. The ownership of 
sea area was given to the Village, and it was the Village that would rent the area to any individuals based on rent agreement. Result of Focused Group Discussion could be explained as following. The harvest from the shallows was subjected to Sasi. The contract of a week would require payment of IDR 3 millions tothe Village. The depth of the rented sea area was measured by the border of the ebb and also by the capacity of the renter to dive into the sea. The sea could be set to Sasi of 2-3 years period, and this period was considered as long enough to maintain the lola. Opening and closing the period of Sasi would require local government to give report to the Church for blessing. Reverend went to the sea wearing Toga (Church Cloth) and did praying by expecting that there was no stealing. The government was equivalent to men, and Church Organization was equivalent to women.

The explanation above indicated that Sasi was the effort by the community to maintain the sustainability of the harvest. Therefore, village government would take Sasi as good initiative in order to reduce the possibility of stealing and also to eliminate the possibility of conflict among citizens who fought for certain sea area. Sasi could also be conducted by individuals for rare crops or certain species of plants, at least for the purpose of conservation. Commodity that was usually subjected to Sasi was orange to conserve the utility of fruit and leaf. The commodity that would be ready for harvest could be subjected to Sasi by the request of the owner after giving note to the Church, and it was done to prevent stealing. Therefore, Sasi had two main principles. One was to maintain the continuous production of certain commodity, where the second was to reduce the possibility of social clash due to stealing and individual conflict.
As explained by Keraf (2010), Marfai (2012), and Juniarta (2013), the implementation of Tnyafar had three important functions, as shown in the following table 1. As indicated by the table, Tnyafar had important functions in the household, respectively being the shelter, being the source of production and consumption, and being the value inheritance system. All these three aspects were related and supporting to each other. All of them underlined the existence of Tnyafar and produced the unity of local wisdom. All activities, from the starting of work until the gratitude during harvest, were done in Tnyafar, and the result was enjoyed by all members of Tnyafar, and even shared with neighboor Tnyafar. The selection of activity to be done in Tnyafar was determined by two things, precisely the determinancy in doing the work and the accessibility of the work. When determinancy and accessibility was hard, fixed-farming in the garden (orchard) was the only option. The expression of Tnyafar aslom was still prevailed onwards, and it possibly developed further when the accessibility to work became easier.

This finding was aligned with Kardooni et al (2014). Their research revealed some indications. Some variables were representing traditional knowledge. Men had higher participation than women. There was a close relation between age and knowledge. Old generation tended to have much traditional knowledge than the young. Result of research by Swarnam et al (2015) had shown that the knowledge of the people about how to process post-harvest coconut into main food had facilitated their livelihood satisfaction activity. This knowledge was passed on the next generation to be the important stock for their living. Even, this knowledge was still relevant in recent days.

Table.1: The Functions of Tnyafar

\begin{tabular}{|c|c|c|}
\hline No & Function & Explanation \\
\hline 1 & Shelter & $\begin{array}{l}\text { Parental time was mostly spent in Tnyafar from Monday to Saturday. The living day of } \\
\text { the household was also occuring in Tnyafar, including resting and gathering with } \\
\text { household members (besides the parent, there was also unschooled children). }\end{array}$ \\
\hline \multirow[t]{6}{*}{2} & $\begin{array}{l}\text { Production and } \\
\text { Consumption }\end{array}$ & The satisfaction of livelihood was done in Tnyafar. \\
\hline & \multirow[t]{2}{*}{ Food Security } & $\begin{array}{l}\text { Garden was planted with crops such as tubers, corn, and rice as main food, and the } \\
\text { excess was sold. }\end{array}$ \\
\hline & & $\begin{array}{l}\text { Coastal area was used for fishing to satisfy the need of protein. The excess was sold or } \\
\text { exchanged with other commodity the household did not possess. }\end{array}$ \\
\hline & $\begin{array}{l}\text { Sustainable Life } \\
\text { Security }\end{array}$ & $\begin{array}{l}\text { Non-food necessity, such as school tuition, was satisfied through longevity plant. The } \\
\text { coconut was one plant that was usually exchanged for fast money. The copra could be } \\
\text { directly sold and becoming the source of household income for non-food need. }\end{array}$ \\
\hline & \multirow{2}{*}{$\begin{array}{l}\text { Strengthening the } \\
\text { Household } \\
\text { Economic }\end{array}$} & $\begin{array}{l}\text { Coastal area was used for sea-grass cultivation to produce additional income, and it } \\
\text { succesfully gave significant contribution to the household. }\end{array}$ \\
\hline & & $\begin{array}{l}\text { The shallow side of the coastal area was providing sea products with quite high } \\
\text { economical value, including sea cucumber and lola. }\end{array}$ \\
\hline
\end{tabular}




\begin{tabular}{|c|l|l|}
\hline 3 & Value Inheritance & $\begin{array}{l}\text { Through Tnyafar, the values of livelihood satisfaction could be inherited to the } \\
\text { descendants. During school holiday, children were taken to Tnyafar at least to help their } \\
\text { parent. All activities in Tnyafar were indirectly learnt and becoming a part of the } \\
\text { sustainable process of knowledge acquisition among the children. } \\
\text { Indeed, local wisdom values in Tnyafar, including Sasi, could also be understood by } \\
\text { children as the knowledge that must be inherited to the next generation. }\end{array}$ \\
\hline
\end{tabular}

Source: Sopamena, 2018

\section{CONCLUSIONS}

The burden of women in Selaru Island was getting heavier due to efforts to maintain Tnyafar local wisdom on agroforestry. Such agroforestry would be a strategy of farmer household livelihood which may impact the position of women in community life. In general, women position faces two contrasting alternatives:

1. They should have better position than before in the context of socio-economic life of Tanimbar communities, recalling that women played important role, or possibly dominant, in fulfilling household necessities, especially when they must choose proper livelihood strategy. This role means that women in Tanimbar incur heavier burden and therefore, their role in the context of socio-economic life of Tanimbar communities must be recovered to what should be the place. The excess of work should be relieved to reduce the burden of Tanimbar women into a harmony, and be manifested as women in their hous ehold life.

2. They may suffer from lower position because the domination of men forces women under pressure in fulfilling household necessities. There is no change of women position in the context of socio-economic life of Tanimbar communities. Fulfilling household necessities and contributing to household income were mandates that must be met by women. In one side, role of women was the articulation of Tnyafar local wisdom in relative with the utilization of natural resources for fulfilling household necessities. In other side, role of women was the manifestation of local wisdom, but it displaced from domestic realm to public realm. It is possible if this role remains in the realm of public sector.

The question includes that whether this local wisdom is compatible with expectation and self-interest of women, or whether women accept their excess role as the manifestation of Tnyafar local wisdom in relative with household livelihood strategy or just accepting the role with sense of perforce and pressure? Further research must understand Tanimbar women in the context of role linkage, livelihood strategy and local wisdom.

The separation of rights and obligations between men and women also occurred in spatial aspect. For instance, the access and control of men and women were separated between public and private spaces. It means that it not only separates the access to natural resources, but also separates their rights to obtain and to manage natural resources. The rights of ownership and the rights of usage of men were associated on de jure perspective, meaning that it was valid based on jurisprudence. Women were associated more with the rights of natural resources on $d e$ facto perspective, precisely only based on a habitual practice.

The rooms separating rights and obligations were mediated by activities crossing space limits. Agroforestry concept was developed through Tnyafar showing that women had activities on land and sea. Besides cultivating annual plants and crops, women in Tnyafar also manage seaweed works. Across the rooms, there will be a path for women to across domestic and public realms. The position of women is the part of Tnyafar activities, on which women do their domestic and public activities, recalling the fact that they must embed themselves into land and sea works.

Tnyafar describes a kind of intact agroforestry through the utilization of long-age plant (annual plant, including coconuts) and short-age plant (corns and tubers), and both plants are arranged together in similar planting area based on the agreement of household. Besides, in Tnyafar processes, seaweed commodities are the supplementary contribution to household income. The utilization of land and sea regions in Tnyafar had shown that agroforestry system was unique and different from the usual. Indirectly, women activities had strengthened the presence of TnyafarAgroforestry not only crossing the borders of land and sea, but also exceeding agroforestry concept itself.

\section{REFERENCES}

[1] Andriani R, Euis Sunarti. 2008. Gender Analysis on Farmers' Family of Paddy and Horticulture in Suburban Areas. [Internet]. [downloaded September 20, 2014. Bogor (ID). Can be downloaded from: http://jurnal.unpad.ac.id/kependudukan/article/view/ doc6/0

[2] Arafura Timor Seas Ecosystem Action Programme., 2011., Coastal Communities in the District of West Southeast Maluku . Atsea. 
[3] Bogdan, R.C and Biklen, S.K., 1982. Methods of Social Research. Boston : Allyn and Bacon Inc.

[4] Cabuy, Reinardus L., Jonni Marwa, Jacob Manusawai and Yohanes Y. Rahawarin. 2012. Nonwoody Plant species of Papuan Island forests, A Sustainable source of food for the local communities. Indian Journal of Traditional Knowledge, Vol 11 (4), Oktober 2012, pp 586-592

[5] Chanamuto, Nicola J.C. and Stephen J.G. Hall., 2015. Gender Equality, Resilience To Climate Change, And The Design Of Livestock Projects For Rural Livelihoods. Journal Gender \& Development, Volume 23, 2015 - Issue 3: Resilience Pages 515530, Published online: 13 Nov 2015

[6] Creswell, John, 1994. Research Design, Qualitative and Quantitative Approach. London : Sage Publications.

[7] Dharmawan AH. 2007. Livelihood and Rural Livelihood System: Livelihood Sociology View of West Mahzab and Mahzab Bogor. [Internet]. [Downloaded September 20, 2014]. Bogor (ID): Bogor Agricultural University. ISSN: 1987-4333, Vol. 02. Can be downloaded from: http://jurnalsodality.ipb.ac.id/jurnalpdf/edisi-1.pdf

[8] Presidential Instruction No.9 / 2000 on Gender Mainstreaming.

[9] Juniarta, HP, Susilo E, Primyastanto M. 2013. Study of Local Wisdom Profile of Coastal Communities of Gili Island Sumberasih Sub-District, Probolinggo District East Java. ECSOFiM [internet]. [downloaded September 9, 2014]; 01 (01): 11-25. Downloaded from http://ecsofim.ub.ac.id/index.php/ecsofim/article/vie $\mathrm{w} / 10$

[10] Kardooni Roozbeh, Fatimah Binti Kari, Siti Rohani Binti Yahaya, and Siti Hajar Yusup., 2014. Traditional Knowledge of Orang Asli of Forests in Peninsular Malaysia. Indian Journal of Traditional Knowledge, Vol 13 (2), April 2014, pp. 283-291., http://hdl.handle.net/123456789/27915

[11] Keraf, AS. 2010. Environmental Ethics. Jakarta [ID] : Kompas. 408 pp.

[12] Marfai MA. 2012. Introduction to Environmental Ethics and Local Wisdom. Yogyakarta [ID] : Gadjah Mada University Press

[13] Moleong. L.J. 1989. Qualitative Research Methodology . Bandung, Remaja Rosda Karya.

[14] Miles, Matthew, B dan A.M. Huberman., 1992. Qualitative Data Analysis: The Source Book About New Methods. UI Press, Jakarta.

[15] Obert Jiri, Paramu L. Mafongoya, Chipo Mubaya, dan Owen Mafongoya., 2016. Seasonal Climate Prediction and Adaptation Using Indigenous
Knowledge Systems in Agriculture Systems in Southern Africa: A Review., Journal of Agricultural Science; Vol. 8, No. 5; 2016, ISSN 1916-9752 EISSN 1916-9760, Published by Canadian Center of Science and Education

[16] Pattiselanno, A.E, E. Jambormias, S.F.W. Thenu, S. Leimaheriwa, H. Amanupunyo, I.P. Siwa, dan J.D. Putuhena., 2015. Agricultural Blue Print of West Southeast Maluku (Cooperation Agribusiness Department Faculty of Agriculture Unpatti and Department of Agriculture District MTB). Kanisius Jogyakarta Publisher.

[17] Scoones I. 1998.Sustainable Rural Livelihood a Framework for Analysis. IDS Working Paper 72. Brigton [UK]: Institute for Development Studies.

[18] Sopamena, Junianita, F., 2018. Konstruksi Gender, Strategi Nafkah , dan Kearifan Lokal (Studi Kasus Tnyafar Di Pulau Selaru Kabupaten Maluku Tenggara Barat). Program Pascasarjana Fakultas Pertanian Universitas Brawijaya Malang (Disertasi). Tidak Dipublikasikan.

[19] Stake, Robert, E., 1995. The Art of Case Study. Sage Publications London New Delhi.

[20] Swarnam Velmurugan; Sai, Tulsi Pawan; Roy, Dam S., 2015. Traditional Farming and Post Harvest Processing of Coconut by Nicobari Tribe. NISCAIR-CSIR, India., IJTK Vol.14(2) [April 2015]

[21] Yin, Robert. K., 1996. Case Study (Design and Method, Interpreting: M.D. Mudzakir). Raja Grafindo Persada, Jakarta. 